\title{
EFFECTS OF DIFFERENT TILLAGE METHODS ON THE SOIL ENZYME ACTIVITY IN SORGHUM CULTIVATED LAND IN A HILLY ENVIRONMENT
}

\author{
WANG, A. P. - XuE, S. T. - Dong, Z. P. - Dong, Q.* \\ College of Agriculture, Shanxi Agricultural University, Taigu 030801, China \\ ${ }^{*}$ Corresponding author \\ e-mail:13834833463@163.com \\ (Received 28 ${ }^{\text {th }}$ Oct 2019; accepted $12^{\text {th }}$ Feb 2020)
}

\begin{abstract}
Through no tillage, deep ploughing, shallow ploughing + straw mulching and deep ploughing + straw mulching, sorghum planting experiments were carried out in hilly areas to study the effects of different tillage methods on soil enzyme activity. The acidity of Sorghum at jointing, flowering and harvesting stages was determined. The results showed that deep tillage and straw mulching could improve soil enzyme activities of sorghum. RS tillage improved soil invertase, acid phosphatase, polyphenol oxidase, catalase, soil urease, soil invertase and alkaline phosphatase activities in the whole growth period of sorghum, and the effects were relatively significant. There were differences between growth periods. At the jointing and flowering stages of sorghum, the protease activity of $\mathrm{R}$ and TS treatments was significant, and the activity of soil beta-glucosidase in T treatment was higher than that in RS treatment. Tillage can change the activity of sorghum soil enzymes and improve soil fertility in Hilly environments. Therefore, the method of Sorghum planting in hilly environment can be reasonably selected according to the growth demand of sorghum soil enzymes.
\end{abstract}

Keywords: deep ploughing, straw mulch, growth period, protease, soil fertility

\section{Introduction}

Sorghum (Sorghum bicolor (L.) Moench) is an annual herb of Gramineae. Its stalks are thicker and erect, basally with root sheaths glabrous or slightly white; leaf ligules dura mater, apex rounded. The ciliated panicles are loose at the edges, the main axis is bare, and the total stem is erect or slightly curved. Caryopsis convex on both sides, light red to reddish brown, $2.5-3 \mathrm{~mm}$ wide at ripening, apex slightly exposed. Spikelets with stalks are about $2.5 \mathrm{~mm}$ long, and linear to lanceolate, flowering and fruiting occurred in June-September. Soil enzymes activity refers to the ability of soil enzyme to catalyze material transformation (Jun et al., 2017). It is usually expressed by the amount of catalytic reaction products per unit of soil or the amount of residual substrates per unit of time. Domestic scholars have done a lot of research on Sorghum planting and growth: Bo (2016) showed that with the increase of planting density, the leaf area per plant of sorghum decreased, the ventilation and light transmission conditions deteriorated, and the ear, ear grain number and 1000-grain weight decreased, which was harmful to the development of sorghum. With the increase of planting density, the number of sorghum leaves did not change significantly. Zhang et al. (2016) studied the sweet sorghum 8 agronomic traits such as the simple correlation, plant height and spike length, section number, stem diameter, sugar content, significantly associated heading stage, plant height and yield of straw, stem length, node number were positively correlated, and straw yields were positively correlated, stem diameter and the grain yield was significantly positively related, and plant height and fresh weight, leaf area per plant were positively correlated, 
were very significant positive correlation, and ear length were very significant negative correlation with thick stems.

Sorghum is the main raw material for liquor brewing. The traditional habit of planting sorghum in southeastern Sichuan is the dominant production area of waxy sorghum in China. The waxy sorghum planted under unique ecological conditions is the preferred raw material for famous liquor manufacturers in Sichuan, Guizhou and Chongqing provinces (Supriya et al., 2017). However, due to the wide range of hills, fewer flat dams, more slopes, small plots and small scale of concentrated production of Sorghum in southeastern Sichuan, some of them adopt the way of planting sorghum in hills. Sorghum planting in hilly environment is more common, the degree of mechanization is very low, the phenomenon of "old, chaotic and miscellaneous" varieties is serious, the cultivation techniques are relatively backward, the control of diseases and insect pests is not in place in time, the docking of production and demand is not keeping pace with other factors, resulting in higher relative cost and poor efficiency of Sorghum planting (Kosmambetova et al., 2017). Under the condition of market economy, sorghum producers should aim at pursuing the highest economic benefits.

Soil enzymes are the general term of enzymes existing in soil, and they are one of the components of soil (Feng et al., 2018). Soil enzyme activity includes not only the enzymes accumulated in the soil, but also the enzymes released from the proliferating microorganisms to the soil. It mainly comes from the cell secretions of animals, plant roots and microorganisms in the soil and the decomposition of residues. Soil enzymes are involved in the synthesis and decomposition of humus, hydrolysis and transformation of organic compounds, plant and animal residues and various redox reactions of organic and inorganic compounds in soil (Xu et al., 2017). These processes are closely related to the release and storage of various nutrient elements in soil, the formation and development of humus in soil, the structure and physical condition of soil. They participate in the whole process of the occurrence and development of soil and the formation and evolution of soil fertility. Therefore, soil enzyme activity directly affects soil fertility and indirectly affects Sorghum yield (Cao et al., 2016). It is a feasible way to optimize the yield of Sorghum in hilly environment from the perspective of improving soil enzyme activity. In this paper, a sorghum cultivation area in hilly environment was selected as the research area, and sorghum was cultivated by different tillage methods to study the effect of Tillage Methods on soil enzyme activity. In order to increase the yield of sorghum, we should improve the activity of soil enzymes and optimize the formation and evolution of soil fertility.

\section{Materials and Methods}

\section{Experimental Design}

The experimental area is located in the hilly area of $29^{\circ} 51^{\prime}, 106^{\circ} 27^{\prime}$ and $244 \mathrm{~m}$ above sea level, with a subtropical monsoon humid climate. This is because there is a small difference in soil enzyme activity between flat land use patterns, while there is a large difference in soil microbial quantity in the hilly area with obvious characteristics. The average slope of the experimental area is between $10^{-6} \sim 10^{-2} \mathrm{~mol} / \mathrm{L}$. The annual total solar radiation is $87,108 \mathrm{~kJ} \cdot \mathrm{cm}^{-2}$, the annual total sunshine time is $1,276.7$ hours, the annual average temperature is $18^{\circ} \mathrm{C}\left(\geq 10^{\circ} \mathrm{C}\right)$, the accumulated temperature is $5,979.5^{\circ} \mathrm{C}$, the highest temperature in summer is about $40^{\circ} \mathrm{C}$ and the average rainfall is $1,133.7 \mathrm{~mm}$. The 
soil of the test plot is purple soil of dry land, with gentle slope and relatively uniform soil fertility. The cultivated soil in hilly environment is irrigated and silted soil with early cultivation and high maturity. Its thickness can reach $30-60 \mathrm{~cm}$. The cultivation layer is light in texture and poor in water retention capacity. The volumetric heat capacity is generally $1-2.5 \mathrm{coke} / \mathrm{cm}^{3} \cdot{ }^{\circ} \mathrm{C}$. Moreover, due to the limiting factor of soil fertility level, the fertility level is quite different.

The experiment was started in April 2018. Four tillage treatments (no-tillage, deep tillage, shallow tillage + straw mulching, deep tillage + straw mulching) were set up. Each treatment set was repeated three times. The area of each treatment plot ranged from 12 to $24.75 \mathrm{hm}^{2}$ and was arranged in random blocks. In order to facilitate experimental recording and improve detection efficiency, the following four methods are set as follows: (1) No-tillage (T): no tillage of the land, plastic film was replaced until the experimental Jiedong; and (2) Deep tillage (TS): tillage $30 \mathrm{~cm}$ of cultivated land with subsoiling shovel after autumn harvest, and rotary tillage, mulching and sowing in spring. (3) Shallow tillage + straw mulching (R): Stalk-straw cutting and shallow harrow suppressionploughing-shallow tillage-fertilization preparation-open-field drilling-weeding, pest control, treatment area $2.4 \mathrm{hm}^{-2}$, straw returning amount of $104 \mathrm{hm}^{-2}$. (4) Deep tillage + straw mulching (RS): Stalk-straw cutting and shallow harrowing to suppress, deep tillagefertilization preparation-open field drilling-weeding, pest control during sorghum harvesting in the previous crop. The treatment area is $2.67 \mathrm{hm}^{-2}$, and the amount of straw returned to the field is about $114 \mathrm{~kg} \mathrm{hm}^{-2}$.

Sorghum was planted uniformly, sowing time was April 20, plant spacing was $20 \mathrm{~cm}$, row spacing was $30 \mathrm{~cm}$, and $7.2 \times 10^{4}$ plants $/ \mathrm{hm}^{2}$ were planted. Unified fertilization measures were adopted. The fertilizers used were urea, diamine phosphate, calcium and potassium chloride. The amount of chemical fertilizer used in each treatment was uniformly N $180 \mathrm{~kg} / \mathrm{hm}^{2}$ and $\mathrm{P}_{2} \mathrm{O}_{5} 95-98 \mathrm{~kg} / \mathrm{hm}^{2}$ per year. Diamine iodate, calcium and potassium chloride were applied on the whole, urea $20 \%$, jointing to heading $20 \%$, heading to flowering $10 \%$, and filling $50 \%$. Irrigation for the whole growth period ranged from 34.1 to $36.3 \mathrm{~m}^{3} / \mathrm{hm}^{2}$. The fertilization, irrigation and management of sorghum cultivated land are the same in four different tillage modes of No-tillage, shallow tillage + straw mulching, deep tillage, deep tillage + straw mulching, which are different only in farming methods. Sorghum cultivation in the experimental area is shown in Figure 1.

\section{Sample Collection and Indicator Determination}

\section{Sampling of soil samples}

In 2018, root soil was collected during the jointing, flowering and harvesting periods of sorghum. During the collection, $2 \mathrm{~cm}$ of topsoil was taken, and $0-20 \mathrm{~cm}$ of root soil was taken for each plot according to the s-shaped sampling method. Soil enzyme activity is different in different areas. In order to ensure the accuracy of experimental data, it is necessary to control the consistent amount of experimental enzymes. Therefore, different plot sizes are needed, and the sampling points of each plot are 90, 80 and 70, respectively. After collecting at multiple points on each plot, the soil is evenly mixed. Some are packaged in sterile, self-sealing bags. They were immediately placed in an ice box and taken back to the lab. $4^{\circ} \mathrm{C}$ refrigerator preservation, soil microbial diversity measurement. The other part of the soil was removed, dried and stored in a $2 \mathrm{~mm}$ screen for the determination of soil enzyme activity and soil nutrient content. 


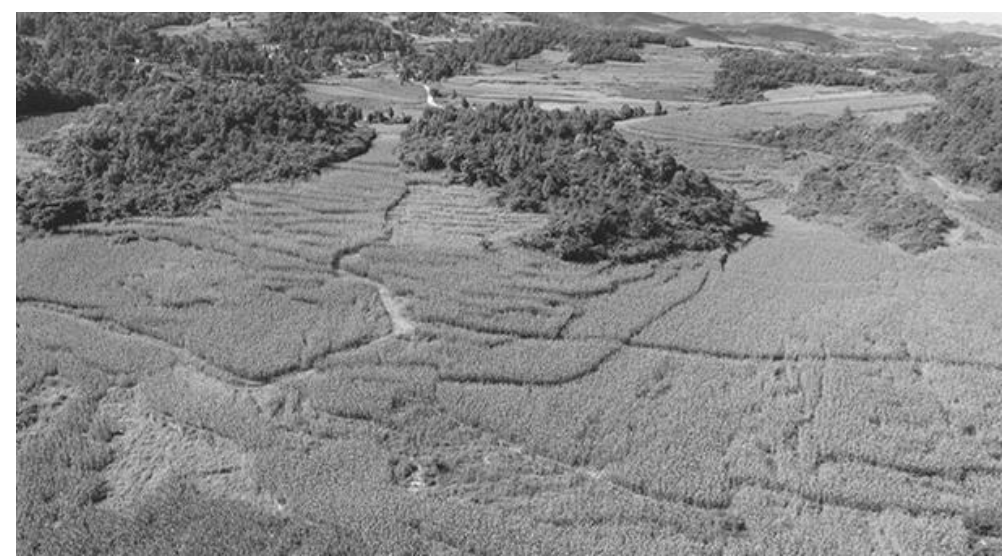

(a) Sorghum planting coverage

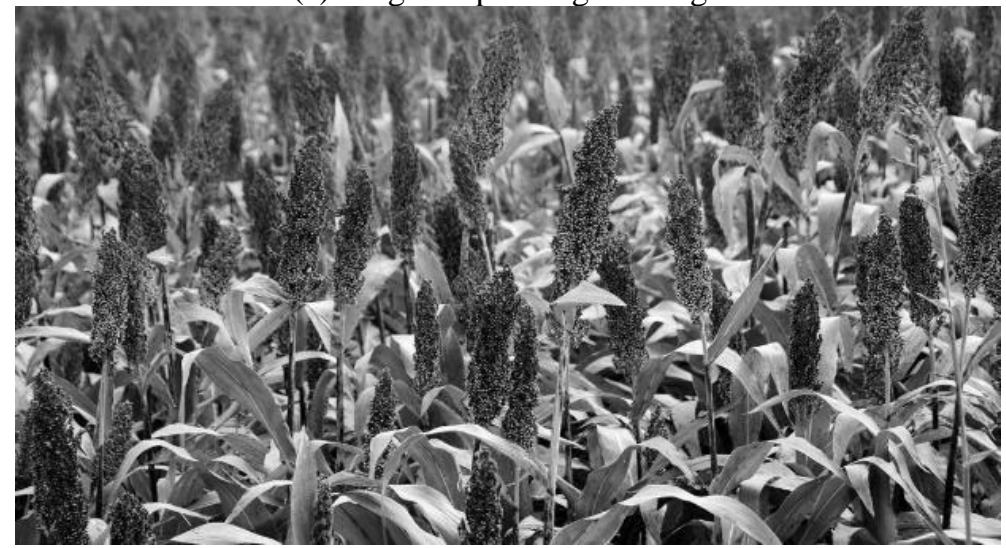

(b) Mature sorghum

Figure 1. Sorghum planting in hilly environment

\section{Method for determination of enzyme activity}

Soil invertase activity (in terms of glucose quality, $\mathrm{mg} \cdot \mathrm{g}^{-1}, 24 \mathrm{~h}, 37^{\circ} \mathrm{C}$ ) was determined by 3,5-Dinitrosalicylic acid colorimetry, soil acid phosphatase (in terms of phenol quality, $\mu \mathrm{mol} \cdot \mathrm{g}^{-1}, 24 \mathrm{~h}, 37^{\circ} \mathrm{C}$ ) and soil polyphenol oxidase (in terms of purple gall quality, $\mathrm{mg} \cdot \mathrm{g}^{-1}, 24 \mathrm{~h}, 37^{\circ} \mathrm{C}$ ) were extracted by Suzhou Keming Biotechnology Co., Ltd. Soil acid phosphatase (S-ACP) kit and soil polyphenol oxidase (PPO) kit (Pan et al., 2018); catalase activity was determined by potassium permanganate titration, expressed in milliliters of potassium permanganate consumed by $1 \mathrm{~g}$ of dry soil after 20 minutes; urease activity was determined by Indigo phenol colorimetry, and transformed into biogenic soil after 6 hours and $1 \mathrm{~g}$ of dry soil. The NH3-N milligram number was expressed; the activity of sucrase was determined by nitrosalicylic acid colorimetric method, expressed by the milligram number of glucose in $1 \mathrm{~g}$ of dry soil after 24 hours (Wen et al., 2017); the activity of alkaline phosphatase was determined by sodium phosphate colorimetric method; the activity of protease was determined by Indigo colorimetric method; and the activity of $\beta$-D-glucosidase was determined by B-Dglucosidase colorimetric method.

\section{Microbial bacteria determination}

The number of bacteria, actinomycetes and fungi were counted by dilution plate method. 


\section{Soil respiration measurement}

Soil respiration flux was measured by Li-8100 soil carbon flux automatic measurement system. Seasonal variation was determined according to the main growth stages of summer sorghum. Fertilizer application and irrigation should be avoided, and the optimum period was about 15 days. Soil respiration was measured at different growth stages, from 8:00 to 20:00 (every 2 hours). It was required that the plastic film should be uncovered on the bare area of the respiratory chamber edge one day before each measurement to remove the accumulated $\mathrm{CO}_{2}$ in the film. On the premise of not disturbing the soil and the PVC ring, the above-ground green plants were cut off from the roots and litter was removed from the circle one day before each determination (Zheng et al., 2017; Faust et al., 2018). In order to reduce the error of temperature to the test in the diurnal variation of respiration, we adopt the sequential measurement method to carry out the cyclic measurement. The flux value can also be automatically calculated by synchronous measurement of $\mathrm{CO}_{2}$ volume fraction in the respiratory chamber, soil temperature, near-surface air temperature and air relative humidity (Wang et al., 2017).

\section{Soil nutrient determination}

Soil organic carbon: using chromic acid redox titration dilution method; total nitrogen: using semi-micro Kjeldahl method; quick-acting potassium: using Extraction Flame photometry; $\mathrm{pH}$ value using potentiometric method.

\section{Data Processing}

The experimental data were unified by Excel 2003, and then analyzed by SPSS 22.0 statistical analysis software for variance, correlation $(\mathrm{p}<0.05)$, and significant difference $(p<0.05)$.

\section{Results}

\section{Effects of Different Tillage Ways on Soil Enzyme Activities in Soil of Sorghum}

\section{Effects of different tillage methods on soil invertase activity in Sorghum}

Soil invertase can hydrolyze sucrose into corresponding monosaccharides and be absorbed by the organism. Enzymatic products are closely related to the content of organic matter, nitrogen and phosphorus in soil, the number of microorganisms and the intensity of soil respiration (Moon et al., 2019). They are important indicators for evaluating soil fertility. Table 1 shows that the invertase activity changes in different treatments are basically the same, that is, with the development of sorghum growth period, the invertase activity in rhizosphere soil of each treatment increased rapidly from jointing stage to flowering stage, and decreased rapidly at maturity stage. The activity of invertase in Sorghum soil was increased by different treatments at different growth stages, but the increment was different among different treatments. At jointing stage, there was significant difference between treatments and $\mathrm{T}$ treatment $(\mathrm{P}<0.05)$, but there was no significant difference between them. At flowering stage, there was significant difference between RS treatment and T treatment $(\mathrm{P}<0.05)$, and the activity of TS and TS treatment was significantly higher than that of T treatment $(\mathrm{P}<0.05)$; at harvesting stage, the activity of RS and R was significantly higher than that of $\mathrm{T}$ and TS treatment $(\mathrm{P}<0.05)$, and other treatments $(\mathrm{P}<0.05)$. There was no significant 
difference between them. The results showed that RS, R and TS treatments could improve the activity of transformation enzymes in Sorghum rhizosphere soil during the whole growth period, and RS treatment had the most significant effect.

Table 1. Changes of invertase activity in Sorghum soil $\left(\mathrm{mg}^{\prime} \mathrm{g}^{-1}\right)$

\begin{tabular}{c|c|c|c}
\hline Handle & Jointing stage & Florescence & Harvest period \\
\hline T & $8.80 \pm 1.08 \mathrm{~b}$ & $58.55 \pm 6.07 \mathrm{c}$ & $47.38 \pm 4.08 \mathrm{~b}$ \\
TS & $15.35 \pm 0.21 \mathrm{a}$ & $79.35 \pm 0.95 \mathrm{ab}$ & $68.63 \pm 9.35 \mathrm{a}$ \\
R & $15.64 \pm 3.07 \mathrm{a}$ & $78.03 \pm 5.71 \mathrm{ab}$ & $57.14 \pm 0.29 \mathrm{~b}$ \\
RS & $16.70 \pm 0.61 \mathrm{a}$ & $89.05 \pm 2.52 \mathrm{a}$ & $78.02 \pm 0.17 \mathrm{a}$ \\
\hline
\end{tabular}

Different lowercase letters in the same column indicate significant difference in $\mathrm{P}<0.05$ level. The same below

\section{Effects of different tillage methods on acid phosphatase activity in Sorghum soil}

Soil acid phosphatase is a kind of enzymes that catalyze the mineralization of soil organic compounds. Its activity directly affects the decomposition and transformation of soil organic compounds and their bioavailability. It is an index to evaluate the direction and intensity of soil phosphorus biotransformation. Table 2 shows that the activity of acid phosphatase in the rhizosphere of sorghum is higher at flowering and ripening stages. The activity of acid phosphatase in the rhizosphere of sorghum treated by RS, R and TS is higher than that of T during the whole growth period of sorghum (Xu et al., 2017). The activity of acid phosphatase in rhizosphere soil under RS treatment at flowering stage was significantly higher than that of other treatments $(\mathrm{P}<0.05)$, but there was no significant difference between other treatments and control. The results showed that RS could significantly increase phosphatase activity in Sorghum rhizosphere soil at flowering stage, and R and TS could also increase phosphatase activity in Sorghum soil, but the effect was not significant compared with RS.

Table 2. Changes of soil phosphatase activity in Sorghum $\left(\mu \mathrm{mol} \cdot \mathrm{g}^{-1}\right)$

\begin{tabular}{c|c|c|c}
\hline Handle & Jointing stage & Florescence & Harvest period \\
\hline T & $87.34 \pm 16.87 \mathrm{a}$ & $97.20 \pm 3.44 \mathrm{~b}$ & $92.08 \pm 13.00 \mathrm{a}$ \\
TS & $95.62 \pm 9.27 \mathrm{a}$ & $102.40 \pm 10.77 \mathrm{ab}$ & $108.32 \pm 14.47 \mathrm{a}$ \\
R & $102.37 \pm 17.26 \mathrm{a}$ & $109.53 \pm 1.85 \mathrm{ab}$ & $108.08 \pm 26.07 \mathrm{a}$ \\
RS & $103.25 \pm 14.00 \mathrm{a}$ & $113.10 \pm 2.07 \mathrm{a}$ & $112.81 \pm 23.66 \mathrm{a}$ \\
\hline
\end{tabular}

\section{Effects of different tillage methods on polyphenol oxidase activity in Sorghum soil}

Soil polyphenol oxidase mainly comes from the decomposition and release of soil biological, plant root exudates and animal and plant residues, catalyzing the oxidation of aromatic compounds into quinones, quinones react with soil proteins, amino acids, sugars, minerals and other substances to form organic matter and pigments, completing soil aromatic compounds recycling for soil environmental remediation. During sorghum growth period, the change trend of polyphenol oxidase activity in rhizosphere of different treatments was similar (Basak et al., 2018). The polyphenol oxidase activity increased rapidly from jointing stage to flowering stage, and then decreased rapidly at harvest stage (Table 3). At jointing stage and harvest stage, the activities of polyphenol oxidase in Sorghum soil treated with RS and R were significantly higher than those 
treated with $\mathrm{T}(\mathrm{P}<0.05)$. At flowering stage, the activity of enzyme under RS and R treatment was higher than TS and T, but only the difference between RS and R reached significant level $(\mathrm{P}<0.05)$. The results showed that $\mathrm{RS}$ and $\mathrm{R}$ could significantly increase the activity of polyphenol oxidase in Sorghum soil, while TS could improve the activity of polyphenol oxidase in Sorghum rhizosphere to a certain extent, but the effect was not significant.

Table 3. Changes of polyphenol oxidase activity in Sorghum soils $\left(\mathrm{mg} \cdot \mathrm{g}^{-1}\right)$

\begin{tabular}{c|c|c|c}
\hline Handle & Jointing stage & Florescence & Harvest period \\
\hline T & $4.74 \pm 1.28 \mathrm{~d}$ & $5.07 \pm 1.33 \mathrm{~b}$ & $4.82 \pm 0.45 \mathrm{~d}$ \\
TS & $8.07 \pm 0.91 \mathrm{ab}$ & $6.57 \pm 1.14 \mathrm{c}$ & $5.20 \pm 3.27 \mathrm{ab}$ \\
R & $6.83 \pm 0.49 \mathrm{bc}$ & $9.10 \pm 1.38 \mathrm{ab}$ & $7.04 \pm 1.72 \mathrm{ab}$ \\
RS & $9.28 \pm 0.22 \mathrm{a}$ & $11.47 \pm 0.26 \mathrm{ab}$ & $9.12 \pm 0.86 \mathrm{a}$ \\
\hline
\end{tabular}

\section{Effects of different tillage methods on catalase activity in Sorghum soil}

Table 4 shows that the catalase activity of all treatments has the same trend during the growth period of sorghum. The catalase activity of all treatments is the highest at jointing stage, then decreases at flowering stage, while the catalase activity of treatments $\mathrm{T}, \mathrm{R}$ and $\mathrm{RS}$ rises slightly at harvest stage. Different tillage treatments could increase the activity of soil catalase in different stages of sorghum. At jointing stage of sorghum, the activity of soil hydrogen peroxide changed from 1.54 to $1.66 \mathrm{~mL} / \mathrm{g}$ (Kylili et al., 2018). Among them, the activity of hydrogen peroxide in RS treatment was higher than that in other treatments, reaching $1.66 \mathrm{~mL} / \mathrm{g}$, and there was no significant difference with other treatments. During the flowering stage of sorghum, the change of catalase activity in soil was $1.30-1.46 \mathrm{~mL} / \mathrm{g}$, and there was no significant difference among different tillage treatments. During sorghum harvest period, the change of soil catalase activity was $1.36-1.58 \mathrm{~mL} / \mathrm{g}$, and the order of soil catalase activity was $\mathrm{RS}>\mathrm{R}>\mathrm{T}>\mathrm{TS}$.

Table 4. Changes of catalase activity in Sorghum soil $\left(\mathrm{mL} \cdot \mathrm{g}^{-1}\right)$

\begin{tabular}{c|c|c|c}
\hline Handle & Jointing stage & Florescence & Harvest period \\
\hline T & $1.54 \pm 0.02 \mathrm{ab}$ & $1.30 \pm 0.01 \mathrm{~b}$ & $1.44 \pm 0.04 \mathrm{~b}$ \\
TS & $1.55 \pm 0.04 \mathrm{ab}$ & $1.41 \pm 0.05 \mathrm{~b}$ & $1.36 \pm 0.04 \mathrm{~b}$ \\
R & $1.56 \pm 0.03 \mathrm{ab}$ & $1.34 \pm 0.01 \mathrm{~b}$ & $1.58 \pm 0.05 \mathrm{~b}$ \\
RS & $1.66 \pm 0.03 \mathrm{~b}$ & $1.46 \pm 0.05 \mathrm{~b}$ & $1.59 \pm 0.06 \mathrm{~b}$ \\
\hline
\end{tabular}

\section{Effects of different tillage methods on soil urease activity in Sorghum}

From Table 5, it can be seen that the trend of urease activity in different growth stages of sorghum is basically the same, and the peak value of urease activity is reached at flowering stage. Soil urease activity changed from $2.34 \mathrm{mg} / \mathrm{g}$ to $2.46 \mathrm{mg} / \mathrm{g}$ at jointing stage of sorghum, and there was no significant difference among different fertilization treatments. At the flowering stage of sorghum, the soil urease activity changed from $2.51 \mathrm{mg} / \mathrm{g}$ to 2.86 $\mathrm{mg} / \mathrm{g}$, and the activity of urease in RS treatment was the highest (Ye et al., 2017). The urease activity in each tillage treatment was RS $>\mathrm{R}>\mathrm{TS}>\mathrm{T}$, and the difference between treatments was small. Soil urease activity changed from $2.05 \mathrm{mg} / \mathrm{g}$ to $2.32 \mathrm{mg} / \mathrm{g}$ during harvest period. The order of size and flowering time of all tillage treatments were the same. RS treatment was significantly higher than T treatment, with an increase of $13.1 \%$. 
Table 5. Changes of catalase activity in Sorghum soil ( $\left.\mathrm{mg} \cdot \mathrm{g}^{-1}\right)$

\begin{tabular}{c|c|c|c}
\hline Handle & Jointing stage & Florescence & Harvest period \\
\hline T & $2.34 \pm 0.003 \mathrm{~b}$ & $2.51 \pm 0.08 \mathrm{ab}$ & $2.05 \pm 0.13 \mathrm{~b}$ \\
TS & $2.34 \pm 0.121 \mathrm{~b}$ & $2.66 \pm 0.13 \mathrm{~b}$ & $2.10 \pm 0.10 \mathrm{bc}$ \\
R & $2.37 \pm 0.06 \mathrm{~b}$ & $2.70 \pm 0.03 \mathrm{~b}$ & $2.13 \pm 0.04 \mathrm{bc}$ \\
RS & $2.46 \pm 0.09 \mathrm{~b}$ & $2.86 \pm 0.06 \mathrm{~b}$ & $2.32 \pm 0.02 \mathrm{c}$ \\
\hline
\end{tabular}

\section{Effects of different tillage methods on invertase activity in Sorghum soil}

Table 6 shows that all tillage treatments can improve soil invertase activity at different stages of sorghum. The changes of soil invertase activity at jointing stage and harvest stage of sorghum are $15.03-25.55 \mathrm{mg} / \mathrm{g}$ and $15.60-34.42 \mathrm{mg} / \mathrm{g}$, respectively. The activities of RS and TS in treatment are significantly higher than those in treatment $\mathrm{T}$ and R. At the flowering stage of sorghum, the change of soil sucrose activity was 21.14$34.3 .7 \mathrm{mg} / \mathrm{g}$, the order of size was RS > TS > R > T. Compared with T treatment, the increase of RS, TS and R were $62.58 \%, 38.55 \%, 21.71 \%$, respectively. The soil enzyme activity of RS treatment was significantly higher than that of T treatment.

Table 6. Changes of invertase activity in Sorghum soils $\left(\mathrm{mg}^{-\mathrm{g}^{-1}}\right)$

\begin{tabular}{c|c|c|c}
\hline Handle & Jointing stage & Florescence & Harvest period \\
\hline T & $15.03 \pm 1.07 \mathrm{a}$ & $21.14 \pm 1.06 \mathrm{a}$ & $15.60 \pm 3.16 \mathrm{a}$ \\
TS & $22.82 \pm 1.47 \mathrm{c}$ & $29.29 \pm 4.07 \mathrm{c}$ & $34.42 \pm 4.31 \mathrm{c}$ \\
R & $16.26 \pm 0.50 \mathrm{~b}$ & $25.73 \pm 1.76 \mathrm{~b}$ & $19.52 \pm 2.80 \mathrm{~b}$ \\
RS & $25.55 \pm 1.48 \mathrm{c}$ & $34.37 \pm 1.86 \mathrm{c}$ & $30.36 \pm 1.23 \mathrm{c}$ \\
\hline
\end{tabular}

\section{Effects of different tillage methods on alkaline phosphatase activity in Sorghum soil}

Table 7 shows that the change trend of alkaline phosphatase activity is basically the same in all growth stages of sorghum. The alkaline phosphatase activity is higher at jointing stage, slightly decreased at flowering stage, increased at harvest stage and reached the peak value. Soil alkaline phosphatase activity was increased by different tillage treatments. Soil alkaline phosphoric acid activity changed from $0.926 \mathrm{~g} / \mathrm{g}$ to $1.205 \mathrm{mg} / \mathrm{g}$ in jointing stage of sorghum. The order of size was RS > TS > R > T. The activity of RS and TS in treatment was significantly higher than that in treatment $\mathrm{T}$, and there was no significant difference between treatment $R$ and treatment $R$. At the flowering stage of sorghum, soil alkaline phosphatase activity changed from $0.933 \mathrm{mg} / \mathrm{g}$ to $1.037 \mathrm{mg} / \mathrm{g}$. The soil alkaline phosphatase activity of RS treatment was $1.037 \mathrm{mg} / \mathrm{g}$ significantly higher than that of $\mathrm{T}$ treatment, and there was no significant difference with other treatments. Soil alkaline phosphatase activity changed from $1.107 \mathrm{mg} / \mathrm{g}$ to $1.40 \mathrm{mg} / \mathrm{g}$ during sorghum harvest, and the order of size was RS > R > TS > T. Among them, RS treatment was significantly higher than T and TS treatment, and there was no significant difference between R treatment and RS treatment.

Table 7. Alkaline phosphatase activity in Sorghum soil ( $\left.m g \cdot g^{-1}\right)$

\begin{tabular}{c|c|c|c}
\hline Handle & Jointing stage & Florescence & Harvest period \\
\hline T & $1.004 \pm 0.008 \mathrm{ab}$ & $0.933 \pm 0.036 \mathrm{ab}$ & $1.107 \pm 0.029 \mathrm{ab}$ \\
$\mathrm{TS}$ & $1.064 \pm 0.013 \mathrm{c}$ & $0.942 \pm 0.014 \mathrm{ab}$ & $1.234 \pm 0.043 \mathrm{bc}$ \\
$\mathrm{R}$ & $1.010 \pm 0.051 \mathrm{bc}$ & $0.972 \pm 0.021 \mathrm{ab}$ & $1.307 \pm 0.039 \mathrm{~cd}$ \\
$\mathrm{RS}$ & $1.104 \pm 0.021 \mathrm{c}$ & $1.037 \pm 0.011 \mathrm{~b}$ & $1.400 \pm 0.020 \mathrm{~d}$ \\
\hline
\end{tabular}


Effects of different tillage methods on soil protease and $\beta$-glucosidase activities in Sorghum

Table 8 shows that there are significant differences in protease activity between different treatments at jointing and flowering stages. The effects of R and TS treatments are significant in the two growth stages, but not in the harvest stage. Table 9 shows that the activity of soil beta-glucosidase is better in $\mathrm{R}$ treatment at different stages of sorghum growth and development, jointing stage and flowering stage, $\mathrm{T}>\mathrm{RS}$, harvest stage, $\mathrm{T}<\mathrm{RS}$.

Table 8. Changes of soil protease activity in Sorghum $\left(\mathrm{mg} \cdot \mathrm{g}^{-1}\right)$

\begin{tabular}{c|c|c|c}
\hline Handle & Jointing stage & Florescence & Harvest period \\
\hline T & $43.23 \pm 1.48 \mathrm{ab}$ & $20.45 \pm 1.20 \mathrm{~cd}$ & $22.01 \pm 1.62 \mathrm{a}$ \\
TS & $13.05 \pm 3.64 \mathrm{~cd}$ & $20.73 \pm 0.27 \mathrm{ab}$ & $21.40 \pm 0.17 \mathrm{a}$ \\
R & $61.05 \pm 3.26 \mathrm{ab}$ & $23.64 \pm 0.64 \mathrm{bc}$ & $21.40 \pm 3.07 \mathrm{a}$ \\
RS & $31.42 \pm 1.67 \mathrm{~cd}$ & $15.10 \pm 1.30 \mathrm{~cd}$ & $23.20 \pm 9.21 \mathrm{a}$ \\
\hline
\end{tabular}

Table 9. Changes of soilß-glucosidaseactivity in Sorghum $\left(\mathrm{mg} \cdot \mathrm{g}^{-1}\right)$

\begin{tabular}{c|c|c|c}
\hline Handle & Jointing stage & Florescence & Harvest period \\
\hline T & $52.82 \pm 1.26 \mathrm{~b}$ & $59.73 \pm 4.28 \mathrm{a}$ & $35.84 \pm 0.59 \mathrm{~b}$ \\
TS & $46.53 \pm 2.02 \mathrm{c}$ & $50.06 \pm 2.28 \mathrm{~b}$ & $29.21 \pm 4.00 \mathrm{c}$ \\
R & $62.79 \pm 0.70 \mathrm{a}$ & $60.02 \pm 2.33 \mathrm{a}$ & $47.16 \pm 1.66 \mathrm{a}$ \\
RS & $42.03 \pm 0.35 \mathrm{~d}$ & $57.00 \pm 1.77 \mathrm{a}$ & $44.09 \pm 1.55 \mathrm{a}$ \\
\hline
\end{tabular}

\section{Correlation Analysis}

Analysis of correlation between soil microbial biomass and soil enzymes (invertase, phosphatase, polyphenol oxidase) activity

Soil enzymes are involved in various soil metabolic processes and energy transformation, and have a good correlation with the number of soil microorganisms. Pearson correlation analysis of soil microbial quantity and soil enzyme activity showed that there was a certain correlation between them (Table 10). Among them, bacteria were positively correlated with acid phosphatase, transformation and polyphenol oxidase; fungi were positively correlated with acid phosphatase and invertase, but not with polyphenol oxidation; actinomycetes were positively correlated with acid phosphatase, invertase and polyphenol oxidase.

Table 10. Number of soil microorganisms and correlation coefficients of soil enzymes under different tillage patterns

\begin{tabular}{c|c|c|c}
\hline Content & Bacteria & Actinomyces & Fungus \\
\hline Acid phosphatase & $0.568^{* *}$ & $0.908^{* *}$ & $0.586^{* *}$ \\
Polyphenol oxidase & $0.468^{* *}$ & $0.699^{* *}$ & 0.323 \\
Invertase & $0.603^{* *}$ & $0.550^{* *}$ & $0.757^{* *}$ \\
\hline
\end{tabular}

** indicates a significant correlation at $\mathrm{P}<0.01$ level and * a significant correlation at $\mathrm{P}<0.05$ level

Correlation between soil respiration rate and activities of soil enzymes (catalase, urease, invertase, alkaline phosphatase, protease, beta glucosidase) and soil nutrients

Soil respiration in this area varies significantly with different growth stages (Figure 2). 


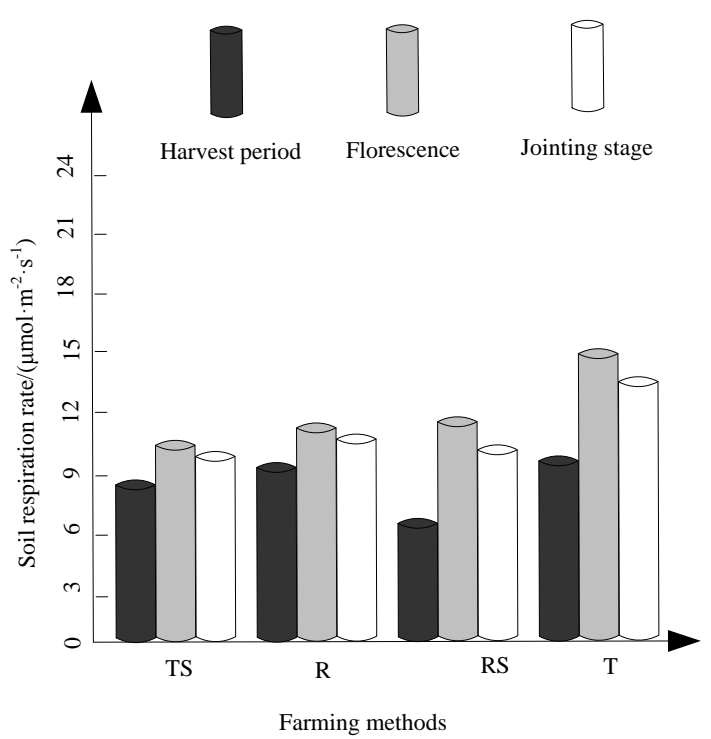

Figure 2. Changes of soil respiration rate during Sorghum growth period under different tillage patterns

In the figure above, $\mathrm{T}$ represents no-tillage, TS represents deep tillage, $\mathrm{R}$ represents shallow tillage + straw mulch, and RS represents deep tillage + straw mulch. It can be seen from figure 2 that soil respiration rates vary at different growing stages. The soil respiration rate at harvest stage was the lowest when RS method was adopted, with a value of $6.5 \mathrm{~mol} \cdot \mathrm{m}^{-2} \cdot \mathrm{s}^{-1}$, and the soil respiration rate at elongation stage was also the lowest with a value of $9.8 \mathrm{~mol} \cdot \mathrm{m}^{-2} \cdot \mathrm{s}^{-1}$. The soil respiration rate at flowering stage was the lowest when TS mode was adopted, and the value was $10.5 \mathrm{~mol} \cdot \mathrm{m}^{-2} \cdot \mathrm{s}^{-1}$.

Soil nutrient content of Sorghum in hilly environment includes organic carbon, total nitrogen, available potassium and $\mathrm{pH}$ value. The change of soil organic carbon content during sorghum growth period is only listed in this paper as shown in Figure 3.

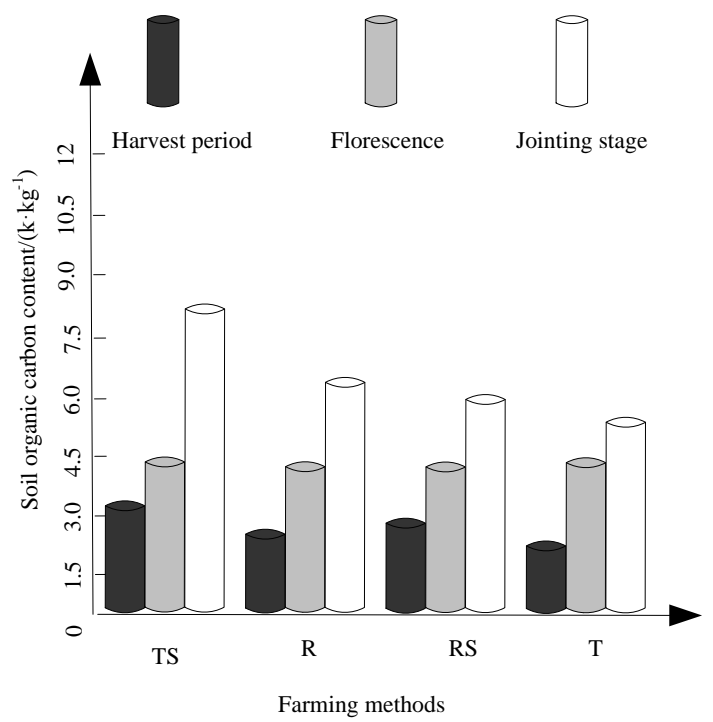

Figure 3. Changes of soil organic carbon content in Sorghum growing period under different tillage patterns 
In the figure above, Trepresents no-tillage, TS represents deep tillage, $\mathrm{R}$ represents shallow tillage + straw mulch, and RS represents deep tillage + straw mulch. It can be seen from Figure 3 that soil organic carbon content varies at different growing stages. The soil organic carbon content in the harvest period was the lowest when $\mathrm{R}$ method was adopted, and the value was $3.3 \mathrm{k} \cdot \mathrm{kg}^{-1}$. The soil organic carbon content in jointing stage was the lowest when T method was adopted, and the value was $5.8 \mathrm{k} \cdot \mathrm{kg}^{-1}$. The soil organic carbon content at flowering stage was the same in all four ways, and the value was $4.5 \mathrm{k} \cdot \mathrm{kg}^{-1}$.

The results of correlation analysis between soil respiration and soil fertility factors showed that (Table 11) the correlation degree between soil nutrients was high, and the correlation among various indicators reached significant or extremely significant levels, which could be used to evaluate the soil fertility. The correlation analysis of soil enzyme activities showed that urease and other enzymes except protease reached a significant level, among which catalase, alkaline phosphatase and $\beta$-glucosidase reached a very significant level $(\mathrm{p}<0.01)$. There was a good correlation between soil respiration rate and other soil fertility indicators except alkaline acid enzyme, total nitrogen, available potassium and $\mathrm{pH}$ value, among which catalase, urease and invertase reached a very significant level $(\mathrm{p}<0.01)$.

Table 11. Relationships between soil respiration rate and soil enzyme activity and soil nutrients

\begin{tabular}{c|cccccccc}
\hline Content & $\begin{array}{c}\text { Respiratory } \\
\text { rate }\end{array}$ & ProteaseCatalase & $\begin{array}{c}\text { Alkaline } \\
\text { phosphatase }\end{array}$ & Urease Invertase & $\begin{array}{c}\text { Beta- } \\
\text { glucosidase }\end{array}$ & $\begin{array}{c}\text { Organic } \\
\text { carbon notal }\end{array}$ Available PH \\
Renpotassiumvalue
\end{tabular}

\section{Discussions}

The total activity of soil enzymes can reflect the soil fertility to a certain extent. Material cycle and energy conversion in soil ecosystem are closely related to soil enzyme activity (Nannipieri et al., 2017). The results showed that different crop tillage, fertilization system and planting methods could cause changes in soil enzyme activity. In this study, we found that the activities of polyphenol oxidase, invertase and acid phosphatase in Sorghum rhizosphere soil were higher at flowering stage (Chen et al., 2016). The main reason is that the enzyme activity is affected by temperature and soil properties. When the soil temperature is low, the activity is weak, and when the soil 
temperature is suitable, the enzyme activity increases. At harvest time, the microbial activity decreases, and the enzyme activity decreases at a certain level. At the same time, the results showed that deep tillage and straw mulching could improve soil enzyme activity in varying degrees, and the effect was most significant under both deep tillage and straw mulching (Sun et al., 2017). This is because straw mulching not only regulates soil temperature, but also has a greater impact on soil organic matter and available nutrients, and can increase the number of soil microorganisms, increase the substrate for microbial transformation, so soil enzyme activity will increase.

The results showed that the effects of different tillage methods on soil enzymes in Sorghum growth period were different. On the whole, straw mulching and deep tillage could significantly improve the activities of soil hydrogen peroxide and urease in Sorghum at different stages. However, there was no significant difference in soil catalase and urease activities among different tillage treatments, except TS, T and T treatments at jointing stage of catalase, which indicated that the activities of hydrogen peroxide and urease in sorghum were less affected by straw mulching and deep tillage. Deep tillage and straw mulching can improve soil acid and alcohol activity. The results showed that alkaline acidase activity of soil treated by deep tillage or straw mulching was higher than that treated by chemical fertilizer. Straw mulching played a key role. Straw mulching improved soil productivity, increased the activity of plants, animals and microorganisms in soil, promoted the secretion of extracellular enzymes and enhanced soil enzyme activity (Wang et al., 2018). Deep tillage or straw returning can improve soil invertase activity, which is similar to the conclusions reported in many literatures. The straw returned to the field also provided the substrate for soil enzymes, provided enough energy for microorganisms, and caused changes in soil enzyme activities (Gopalsamy et al., 2017).

The correlation between urease, alkaline phosphatase, sucrose alcohol, protein alcohol, catalase and beta-glucosidase and soil respiration rate were studied in this experiment to provide basis for improving soil enzyme activity. The results showed that there was a good correlation between soil respiration and soil enzyme activity (except alkaline phosphatase) (Chen, 2017). In addition, the effect of growth period on soil respiration rate should not be neglected. This study found that the respiration rate of Sorghum at jointing stage and before jointing stage was higher than that at flowering and harvesting stage. This may lead to a large loss of soil organic carbon and an increase in $\mathrm{CO}$ release from soils caused by early tillage and sowing, on the other hand, it may be caused by early irrigation. The increase of water content promoted root respiration and the activity of biological community, which enhanced soil respiration.

\section{Conclusions}

This study analyzed the soil enzyme activity of sorghum under different tillage methods at different growth stages. The activities of sucrase, acid phosphatase, polyphenol oxidase, catalase, soil urease, soil invertase and alkaline phosphatase in deep tillage and straw mulching were detected by colorimetry. Under tillage, shallow tillage + straw mulch and deep tillage, enzyme activity was significant. Protease activity was significantly different between treatments at jointing and flowering stages. In the two stages of growth, R treatment and TS treatment were effective. The activity of soil glucosidase was better during the growth, jointing, flowering, ripening, harvesting and ripening of sorghum. Using li-8100 soil carbon flux automatic measurement system, it 
was proved that soil microbial quantity was positively correlated with soil enzymes, bacteria and actinomycetes were positively correlated with acidity, invertase and polyoxygenase, and fungi were positively correlated with acid phosphatase and invertase. Choose deep tillage and straw mulching cultivation, therefore, to improve the soil microorganism quantity and activity, to the growth of sorghum in the hilly environment to build a good ecological environment, to keep the hilly ecosystem sustainable production capacity at the same time is important, then can be tested with different temperature experiment indexes such as, in order to promote the further development of this part.

\section{REFERENCES}

[1] Basak, B. B., Gajbhiye, N. A. (2018): Herbage yield and bioactive principle of senna as influenced by micronutrient application in soil. - Journal of Environmental Biology 39(1):43-49.

[2] Bo, T. (2016): Influence of Combined Soil Heavy Metal Pollution on Soil Enzyme Activity in the $\mathrm{Pb}-\mathrm{Zn}$ Mining Area of Southern Shaanxi. - Journal of Computational \& Theoretical Nanoscience 13(2):1147-1152.

[3] Cao, R., Wu, F. Z., Yang, W. Q., Xu, Z. F., Tani, B., Wang, B., Li, J., Chang, C. H. (2016): Effects of altitudes on soil microbial biomass and enzyme activity in alpine-gorge regions. - Ying Yong Sheng Tai Xue Bao 27(4):1257-1264.

[4] Chen, S. T., Sang, L., Zhang, X., Hu, Z. H. (2016): Effects of warming and straw application on soil respiration and enzyme activity in a winter wheat cropland. Huanjing kexue 37(2):703-709.

[5] Chen, C. (2017):Safety evaluation of electromagnetic environment around electric vehicle during wireless charging. - Automation \& Instrumentation232(02):11-13, 17.

[6] Faust, S., Kaiser, K., Wiedner, K., Glaser, B., Joergensen, R. G. (2018): Comparison of different methods for determining lignin concentration and quality in herbaceous and woody plant residues. - Plant and Soil 433(1-2):7-18.

[7] Feng, B. G.,Guo, P.,Li, L. H., Sun, Y., Chen, W. W. (2018): Effect of Nano-TiO 2 on Mass Ratio of Nitrate Nitrogen and Activity of Nitrate Reductase in Soil. - Journal of Jilin University (Science Edition) 56(06):1570-1576.

[8] Gopalsamy, A., Narayanan, A., Liu, S., Parikh, M. D., Kyne, R. E. Jr., Fadeyi, O., Tones, M. A., Cherry, J. J., Nabhan, J. F., LaRosa, G., Petersen, D. N., Menard, C., Foley, T. L., Noell, S., Ren, Y., Loria, P. M., Maglich-Goodwin, J., Rong, H., Jones, L. H. (2017): Design of potent mRNA decapping scavenger enzyme (DcpS) inhibitors with improved physicochemical properties to investigate the mechanism of therapeutic benefit in Spinal Muscular Atrophy (SMA). - Journal of Medicinal Chemistry 60(7):3094-3108.

[9] Jun, S. Y., Walker, A. M., Kim, H.,Ralph, J., Vermerris, W., Sattler, S. E., Kang, C. H. (2017): Enzyme activity and substrate specificity of the major cinnamyl alcohol dehydrogenases in sorghum. - Plant Physiology 174(4):2128.

[10] Kim, S., Li, G., Han, S. H.,Kim, H. J., Kim, C., Lee, S. T., Son, Y. (2018): Thinning affects microbial biomass without changing enzyme activity in the soil of PinusdensifloraSieb. etZucc. forests after 7 years. - Annals of Forest Science 75(1):13.

[11] Kosmambetova, G. R., Kalchuk, N. S., Didenko, O. Z., Strizhak, P. E. (2017): Comparative study of magnesia-supported highly-dispersed $\mathrm{CuO}$ solids prepared by different methods in $\mathrm{CO}$ oxidation. - Canadian Journal of Chemical Engineering 95(8):1510-1517.

[12] Kylili, A., Fokaides, P. A., Ioannides, A., Kalogirou, S. (2018): Environmental assessment of solar thermal systems for the industrial sector. - Journal of Cleaner Production 176:99-109. 
[13] Moon, C., Ahn, Y., Lee, T., Hwang, Y. (2019): Importance of microbial adaptation for concentrate management in wastewater reuse process. - Energy \& Environment 30(4):719-731.

[14] Nannipieri, P., Trasar-Cepeda, C., Dick, R. P. (2017): Soil enzyme activity: a brief history and biochemistry as a basis for appropriate interpretations and meta-analysis. Biology \& Fertility of Soils 54(5):11-19.

[15] Pan, Z., Baerson, S. R., Wang, M., Bajsa-Hirschel, J., Rimando, A. M., Wang, X., Nanayakkara, N. P. D., Noonan, B. P., Fromm, M. E., Dayan, F. E., Khan, I. A., Duke, S. O. (2018): A cytochrome P450 CYP71 enzyme expressed in Sorghum bicolor root hair cells participates in the biosynthesis of the benzoquinone allelochemicalsorgoleone. New Phytologist 218(2):616.

[16] Sun, X., Shi, J., Ding, G. (2017): Effects of arbuscularmycorrhiza and drought stress on plant growth and mortality of forage sorghum. - Applied Soil Ecology 119(2017):384391.

[17] Supriya, M., De, T., Christopher, R. (2017): Effect of temperature on lysosomal enzyme activity during preparation and storage of dried blood spots. - Journal of Clinical Laboratory Analysis 32(1): e22220.

[18] Wang, L.,Tang, P. W., Yan, W., Gao, X., Wang, E. (2017): Influence on power quality and electromagnetic environment to electric vehicle charging pile. - Journal of Power Supply 15(3):91-99.

[19] Wang, L., Ma, L., Sun, J., Zhang, Y., Zhou, Q., Wu, Z., He, F. (2018): Effects of different aquaculture methods for introduced bivalves (Hyriopsiscumingii) on seston removal and phosphorus balance at the water-sediment interface. - Journal of Freshwater Ecology 33(1):251-265.

[20] Wen, J., Liu, H., Xiao, S., Li, X., Fang, K., Zeng, M., Tang, Z., Cao, S., Li, F. (2017): Comparison of mid-term efficacy of spastic flatfoot in ambulant children with cerebral palsy by 2 different methods. - Medicine 96(22): e7044.

[21] Xu, Z. W., Yu, G. R., Zhang, X. Y., He, N. P., Wang, Q. F., Wang, S. Z., Wang, R. L., Zhao, N., Jia, Y. L., Wang, C. Y. (2017): Soil enzyme activity and stoichiometry in forest ecosystems along the North-South Transect in eastern China (NSTEC). - Soil Biology \& Biochemistry 104(1):152-163.

[22] Ye, Y. Y., Luo, Y., Wang, Y., Lin, M., Xiang, P., Ashraf, M. A. (2017): Relation between diversity of phytoplankton and environmental factors in waters around Nanri Island. Applied Ecology and Environmental Research 15(3):241-252.

[23] Zhang, M. Z., Niu, W. Q., Xu, J., Li, Y. (2016): Influences of micro-irrigation and subsoiling before planting on enzyme activity in soil rhizosphere and summer maize yield. - Chinese Journal of Applied Ecology 27(6):1925-1934.

[24] Zheng, H., Liu, Y., Zhang, J., Chen, Y., Yang, L., Li, H., Wang, L. (2017): Factors influencing soil enzyme activity in China's forest ecosystems. - Plant Ecology 219(1):3144. 